\title{
リング圧縮試験での摩擦せん断係数に及ぼす 試験条件の影響*
}

\begin{abstract}
佃 誠 ${ }^{* *}$. 高田 与男 ${ }^{* *} \cdot$ 尾崎 幸一**
Effect of test conditions on measuring friction factor by ring compression*

UDC:669. $715: 620.173: 539.386$

Makoto TSUKUDA**, Kumio TAKADA** and Koichi OZAKI**

Variables in the ring compression test concerning the friction factor $(\mathrm{m})$ such as specimen size, thickness of lubricant film, surface roughness of specimen and die, temperature difference between specimen and die, and compression speed were examined using 2014 alloy. The surface roughness and the thickness of film have the most important effect on the friction factor, and the other variables have a little effect. The minimum thickness of the lubricant film to maintain lubricity corresponds to a half of the sum of roughness on the die and specimen.
\end{abstract}

(Received March 6, 1979)

\section{1. 緒言}

潤滑は鍛造加工においても重要な因子で潤滑状態によ り成形荷重やメタルフローが変動する。アルミニウム合 金熱間鍛造法では近年ほとんど抜き勾配がなく，しかも 薄い肉厚で寸法精度の高い精密鍛造法や，型割り面のメ タルフローを悠しく管理しなければならないシームレス 鍛造法の技術が発達してきた。このためにも潤滑凬の重 要性がますます高くなつてきている。

潤滑性の定量的な評価には，鍛造変形過程における摩 擦係数を求めなければならない。摩擦係数の測定に種々 の試験方法が提唱されているが1),2),3)，これらの中で高 温で比較的簡単に試験でき，しかも試験片を塑性変形し て測定するリング圧縮試験法4) が最も実用的な方法であ ると考える。

リング圧縮試験法は広く用いられており，これで潤滑

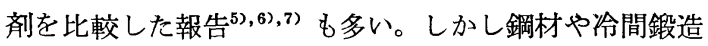
用の潤滑剂に関するものが多く，アルミニウム合金熱間 鍛造用を目的とする報告は少ない。しかも試験方法すな わち実験条件の影響を詳述した報告は見当らない。

一定の条件で潤滑剤を比較するためには，その潤滑剤 の特性が発揮できるような実験条件を選定しなければな らない。

本研究で汢各種の潤滑剤を評価するにあたり，実際の
鍛造作業条件に近くして，かつ標準的な実験条件を明ら かにするために, リング試験片の寸法・塗膜厚さ・金敷 および試験片の表面粗さ・圧下速度について摩擦せん断 係数 (friction factor) との関係を求めた。この結果は鍛 造現場での潤滑に対する標準作業管理としてリング圧縮 試験を実施する場合に有益であろう。

\section{2. 実験方法}

\section{1 実験装置}

リング圧縮試験には圧下速度を $1.0 \sim 7.8 \mathrm{~mm} / \mathrm{sec}$ に調 整できる㹂型1000 ton 油圧プレスを用い, Fig. 1 に示す 圧縮装置で実験した。圧縮荷重を密封型200 ton ロードセ ルで，圧下量すなわち上部金敷の変位をひずみゲージ式 変位計で検出した。変位は圧縮量と圧下速度を制御する ために測定した。

金敷は JIS-SKT-4 焼入れ燃もどし処理材を用い， $\phi$ $150 \times$ t $50 \mathrm{~mm}$ で，圧縮面は表面粗さが $\mathrm{R}_{\max }$ で $2.0 \mu$ となるよらに研摩した。金敷をくりかえし使用すると表 面粗さが若干粗くなるが2.5 $\mu$ 以下には保つことができ た。

試験片と金敷の温度は上・下金敷に㨀入した CA熱電 対で検出し,Fig. 1 に示した付設の電気炉で所定の圧縮 試験温度となるように調整した。

\section{2 リング試験片}

* 軽金属学会第51回秋期大会 (51-11) にて一部を講演発表した。

** 株式会社神戸製鋼所 (名古屋市)。Kobe Steel Ltd.(Nagoya). 


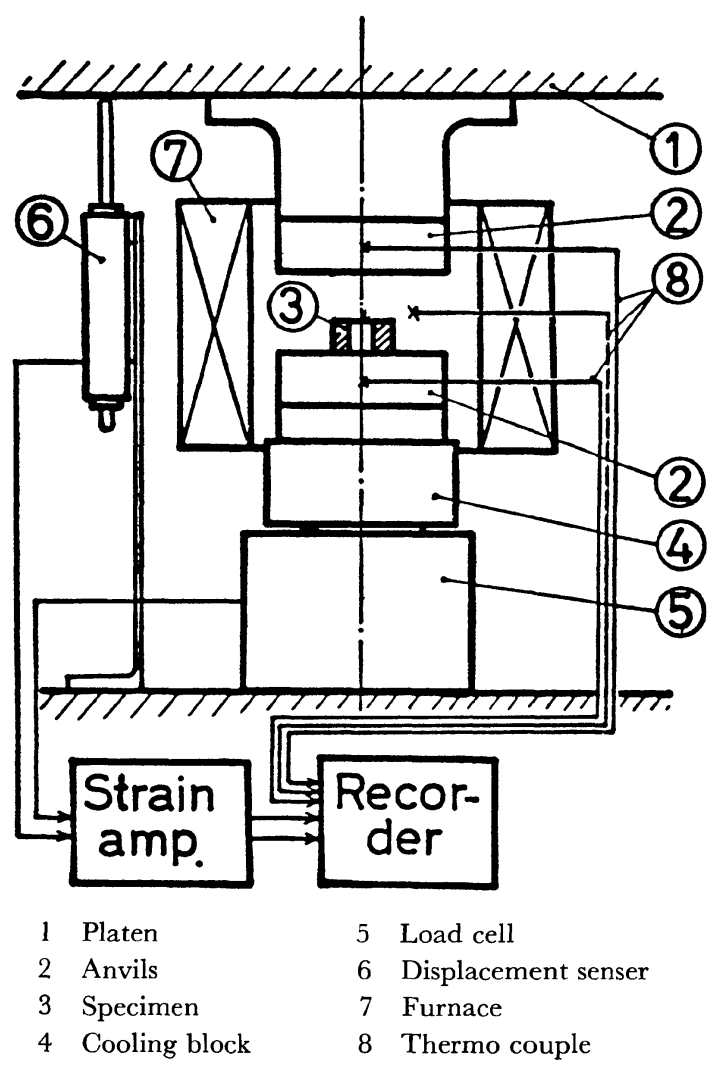

Fig. 1 Apparatus for compression test.

リング試験片は化学成分が Al-4.48\% Cu-1.09\% Si$0.73 \% \mathrm{Mn}-0.63 \mathrm{Mg}$ の2014 合金 $\phi 500 \mathrm{~mm} \mathrm{DC}$ 鋳塊で, 結晶粒がほぼ揃つている内層部 $\phi 300 \mathrm{~mm}$ から切出し た。鋳塊の組織は等軸晶で，平均ミク口結晶粒径は 250 〜300 $\mu$ であつた。鋳塊には均熱処理を $495^{\circ} \mathrm{C} \times 24 \mathrm{hr}$ で 実施した。

\section{3 実験条件}

試験片の形状は外径 : 内径 : 高さの比を $6: 3: 2$ と 一定にした。試験片寸法の影響を外径 $30.0 ， 50.0 ， 75.0$ $\mathrm{mm}$ の 3 種類の試験片で求めた。

潤滑剤には油性で固形分 $10 \%$ のコロイダル黒鉛の市販 潤滑剂を用いた。原液を灯油で10倍に希釈し，金敷表面 にスプレーした。この潤滑剤の黒鉛純度は $99.5 \%$ ，平均 粒径 $1 \mu$ と称している。

潤滑昘のスプレー方法は圧縮試験温度 $350^{\circ} \mathrm{C}$ に保持し た金敷に，塗膜の厚さがほぼ均一に塗布できるよう金敷 中心から約 $400 \mathrm{~mm}$ の位置で $45^{\circ}$ の方向から塗装用スプ レーガンによつて空気圧 $4.5 \mathrm{~kg} / \mathrm{cm}^{2}$ で噴霧した。塗膜 の厚さは試験毎に下部金敷表面で圧縮試験に関与しない 隅の部分に, $30 \times 30 \times \mathrm{t} 4.5 \mathrm{~mm}$ の鋼板を置いて潤滑剂 を噴霧し，磁気抵抗膜厚計で測定した。この方法を採用 するにあたつて，上・下金敷の塗膜厚さを測定し，小鋼
板での膜厚で充分代表しうることを検定した。

上下金敷に潤滑剂をスプレーし，あらかじめ別の電気 炉で圧縮試験温度 $\pm 20^{\circ} \mathrm{C}$ に加熱した試験片を塗膜を損傷 しないように注意して下金敷上に置き，上金敷を試験片 直上に吊下げた状態で圧縮試験温度士 $2^{\circ} \mathrm{C} に 30 \mathrm{~min}$ 保持 してから圧縮試験を開始した。

\section{4 摩擦せん断係数の測定}

リング試験片を圧縮し, 変形前と変形後の内径（それ ぞれ $\mathrm{ID}_{0}, \mathrm{ID}$ とする) と高さ（それぞれ $\mathrm{H}_{0}, \mathrm{H}$ とする) から金敷と試験片との間の平均的な摩擦係数 $(\mu)$ あるい は摩擦せん断係数 $(\mathrm{m})$ を求める方法は最初久能木 ら ${ }^{8)}$ が 行なつた。その後, 実際の変形挙動により精度良く近 似させるために理論的解析手法の改善が行なわれてい

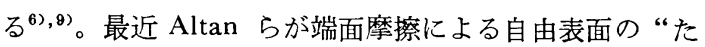
る形変形”をも考慮した理論解析を上界法で行ない，摩 擦せん断係数について圧下率と試験片内径の減少率との 関係を求め，それを検量曲線にして報告している4。

これによれば $\mathrm{m}$ 值は $\mathrm{ID}_{0}, \mathrm{ID}, \mathrm{H}_{0}$ および $\mathrm{H}$ を測定し， 内径減少率を $\left(\mathrm{ID}_{0}-\mathrm{ID}\right) / \mathrm{ID}_{0} \times 100$, 圧下率を $\left(\mathrm{H}_{0}-\mathrm{H}\right) / \mathrm{H}_{0}$ $\times 100$ として計算すると, 検量線から $\mathrm{m}$ 值を求めること ができる。

$\mathrm{m}$ 值は圧縮潤滑面に作用する摩擦せん断力 $(\tau)$, 鉎造 材料の平均変形抵抗 $(\bar{\sigma})$ とによつて次式の関係で表わ される。

$$
\tau=\mathrm{m} \cdot \bar{\sigma} / \sqrt{3}
$$

Altan らは圧縮過程での $\tau, \mathrm{m}$ は一定であると仮定し て解析した。 $\mathrm{m}$ 值は圧縮過程でのメタルフローの中立面 の位置すなわち中立半径に対応して定まり, $\mathrm{m}$ 值と内径 変化との関係は次のようになる。 $\mathrm{m}$ 值が 0 の場 合，す なわち理想潤滑状態では, 中立面はリングの中心軸と一 致する。摩擦がある状態では，てが大きいほどすなわち $\mathrm{m}$ 值が大きいほど中立面が外周側に移動する。理想潤滑 状態および中立面の位置がリングの内径よりも中心側に ある場合には圧縮とともに内径と外径が広がる。中立面 が内径と外径の間にある場合には圧縮とともに内径が縮 まり外径が広がる。 $\mathrm{m}$ 值が 1.0 においては，いわゆる完 全固着状態となり, 内径の減少量が最む大きくなる。

本研究では Altan らの検量線をもとにして, $m$ 值の 間隔を比例配分法でさらに細分した曲線を作つて $\mathrm{m}$ 值 を求めた。

\section{3. 実験結果および考察}

\section{$3.1 \mathrm{~m}$ 值に及ぼす試験片形状の影響}

2014合金試験片の外径：内径：高さの比を $6: 3: 2$ に一定とし, 外径が $30.0 ， 50.0 ， 75.0 \mathrm{~mm}$ のリン゙試験 片により，潤滑剤として厚さ0. $2 \mathrm{~mm}$ のテフロンシート 
Table 1 Effect of dimension on friction factor $(\mathrm{m})$. Ratio of out side dia.: inside dia.: height $=$ 6: $3: 2$ is same. Lubricant is $0.2 \mathrm{~mm}$ Teflon sheet.

\begin{tabular}{c|c|c|c}
\hline \multirow{2}{*}{ out side dia. (mm) } & \multicolumn{3}{|c}{ reduction in height (\%) } \\
\cline { 2 - 4 } & 25 & 35 & 50 \\
\hline 30.0 & 0.04 & 0.05 & 0.07 \\
\hline 50.0 & 0.05 & 0.07 & 0.08 \\
\hline 75.0 & 0.06 & 0.08 & 0.09 \\
\hline & 0.06 & $0.05^{*}$ & $0.07 *$ \\
\hline
\end{tabular}

* renewed lubricant.

を用い圧縮試験をした。圧縮試験温度 $100^{\circ} \mathrm{C}$, 圧下率 25 , $35,50 \%$ で $\mathrm{m}$ 值を求めた。テフロンシートを用いたの は $200^{\circ} \mathrm{C}$ 以下では潤滑性が非常に良好であることと， シ ートなので圧縮前の潤滑膜厚さが一定であるためであ る。

その結果を Table 1 に示す。試験片の径が大きくな るとともに $\mathrm{m}$ 值はやや大きくなり，また圧下率が増す につれて大きくなる。変形が進むにつれて $\mathrm{m}$ 值が増加 するのは，圧縮とともに潤滑膜が薄くなり，一方試験片 の表面は粗くなる ${ }^{10}$ ために摩擦力が増加した結果と考え られる。この証明として $\phi 75.0 \mathrm{~mm}$ の試験片で $25 \%$ 圧縮 してから，テフロンシートを新しいのに替えてさらに圧 縮して求めた $\mathrm{m}$ 值も Table 1 に併記した。潤滑膜が新 しくなるので, 連続して圧縮した場合よりも $\mathrm{m}$ 值が小 さい值となつている。

大きな試験片ほど $\mathrm{m}$ 值が大きくなる原因は明らかで はないが，大きさの影響は圧下率の影響よりも小さい。 試験片が小さすぎると寸法計測の䛊差が大きくなり，こ れが $\mathrm{m}$ 值に影響する。 また圧縮面積すなわち潤滑面積 が小さいと塗膜の不均一さの影響の程度が大きくなり, これが $\mathrm{m}$ 值の偏差に効いてくることも考えられる。

一方 $\phi 75 \mathrm{~mm}$ の試験片で $50 \%$ 圧下すると厚さが 12.5 $\mathrm{mm}$ となり, この厚さは精密鍛造品の肉厚としては厚す ぎる。試験条件を実際の鍛造作業条件に近つけるため に，製品肉厚とほぼ同等で，かつ比較的大きな試験片と して $\phi 50 \mathrm{~mm}$ が適当である。 $\phi 50 \mathrm{~mm}$ 試験片を $50 \%$ の 圧下率で圧縮すると厚さが $8 \mathrm{~mm}$ によりこれはやや厚 目の精密鍛造品の肉厚に相当する。

リング圧縮試験片の大きさとして $\phi 50 \mathrm{~mm}$ を用いる ことにした。

\section{2 潤滑膜厚さの影響}

鍛造作業においては金型への潤滑をほとんどの場合ス プレーで行なつている。塗膜の厚さはスプレーガンの単 位時間当りの噴霧量が一定であれば潤滑液中の固形分濃

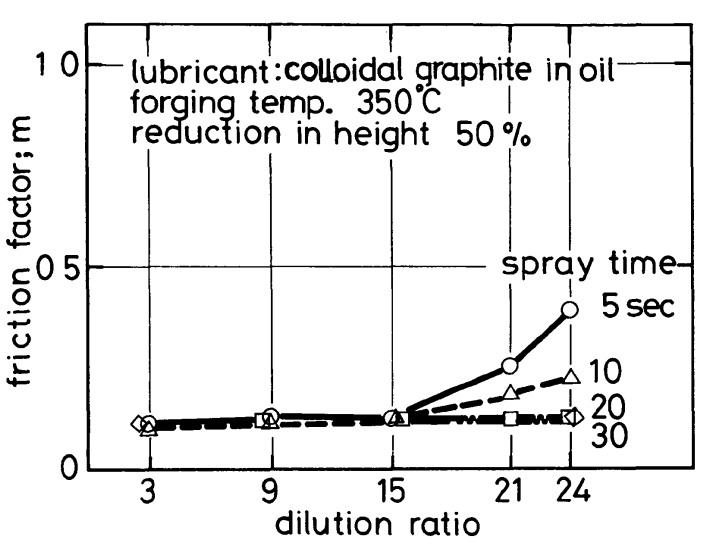

Fig. 2 Effects of dilution and spray time on triction factor.

度とスプレー時間に比例する。しかし実測してみるとス プレー開始直後の短い時間のらちに厚くなり, それ以後 はスプレー時間に比例して膜厚が増加する。この初期の 厚さは黒鉛平均粒径の $1 \sim 2$ 倍であり,これは新しい金 敷表面に黒鉛の $1 \sim 2$ 粒子分がまず付着し, その後は黒 鉛層の上に積み重なることを意味している。また最初に 黒鉛粒が金属表面に付着する場合に比べて，すでに黒鉛 層ができた上に積み重なるほらが付着しにくいために, スプレー時間当りの膜厚増加が少なくなる。本研究には 用いていないが，水溶性あるいはエマルジョン型の潤滑 剤の付着性は油性とかなり差があり, 油性が最も良い。 また金敷の温度や潤滑剤中の添加物などの影響も受け る。したがつて所定の膜厚に塗布するための条件は潤滑 剤毎に設定しなければならない。

しかし塗布した膜厚と潤滑性とには一定の関係があ る。Fig. 2 に油性コロイダル黒鉛を用い，潤滑剤のスプ レー条件を変えることにより塗膜厚さを変えて $\mathrm{m}$ 值を 測定した結果を示す。圧縮試験温度 $350^{\circ} \mathrm{C}$, 圧下率は 50 \%である。希釈倍率が小さいほど，スプレー時間が長い ほど塗膜は厚くなる。しかし $\mathrm{m}$ 值は希釈倍率 $3 \sim 15$ 倍 ではスプレー時間によらず一定なのに，21，24倍になる とスプレー時間が短いほど $\mathrm{m}$ 值が大きくなる。

Photo 1 に圧縮したリングの外観を示す。 $\mathrm{m}$ 值が大き い場合には潤滑膜が不均一であることが見受けられる。

Fig. 2 の結果を塗膜厚さと $\mathrm{m}$ 值との関係として書き 改めると Fig. 3 のようになる。 $\mathrm{m}$ 值は膜厚が約 $2.5 \mu$ よ り厚い場合には一定であるが，これより薄くなると急に 増大する。これは膜厚が薄すぎると，いわゆる潤滑切れ を生じて $\mathrm{m}$ 值が増大することを示している。試験に供 する潤滑剤の潤滑性が保たれながら変形するためには最 小限以上の塗膜厚さが必要となる。

\section{3 表面粗さの影響}

Fig. 4 に金敷の表面粗さを $2.0 \sim 2.8 \mu$ にし, 試験片 


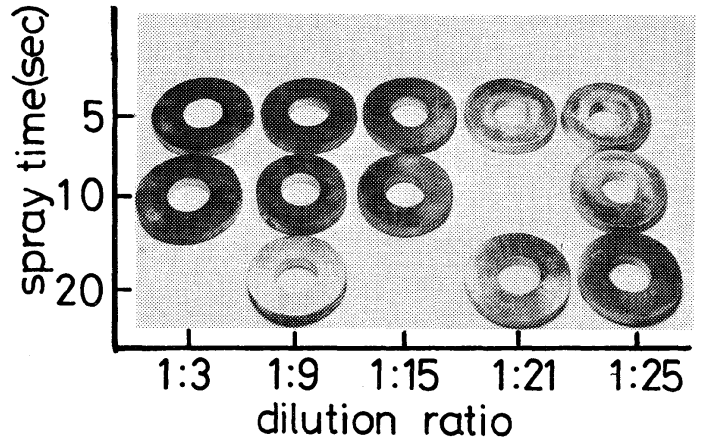

Photo 1 Apperance of compressed ring specimens.

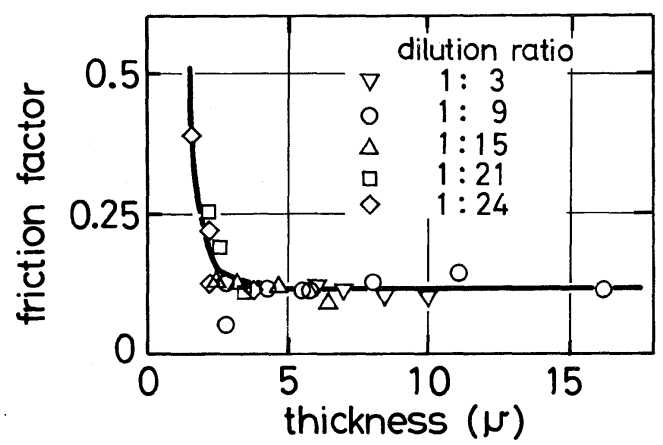

Fig. 3 Effect of film thickness of lubricant on friction factor.

の表面粗さを0.1〜36 $\mu$ に変えて圧縮試験した場合の $\mathrm{m}$ 值を示す。潤滑剂の膜厚は10 10 で，圧縮試験条件は 3.2 項と同様である。

機械加工後の試験片の表面粗さは約 $3.6 \mu$ である。こ れを\#100エメリー研摩によつて約 $12 \mu$ に, バフ研摩に て約 $0.1 \mu$ にしたまたサンドブラストで約 $36 \mu$ にた。

試験片の表面粗さが $3.6,12 \mu$ での $\mathrm{m}$ 值が小さく，ほ

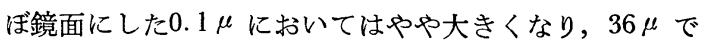
はさらに大きな $\mathrm{m}$ 值になつた。

潤滑性を保ちながら変形するには，まず金敷・試験片 の閒に潤滑剂が閉じ込められていなければならない。こ れには金敷・試験片の表面粗さが影響する ${ }^{10)}$ 。潤滑膜厚 さにくらべて表面粗さが大きいと金敷と試験片の凸部が 潤滑膜を突抜けて接触する部分が多くなる。すなわち境 界潤滑状態の接触率が変形の初期から高いために摩擦力 が大きくなる。Fig. 4 の結果では表面粗さ36 $\mu$ の場合が これに相当する。

表面粗さ $\mathrm{R}_{\max }$ は表面の凹凸の最大深さの平均值であ るから，この四凸をV溝状と仮定すれば，潤滑剤を溝に 埋め込むためには，溝の体積に相当する黒鉛量が必要と なる。これを黒鉛の膜厚で表わすと表面粒さの $1 / 2$ とな る。このこと注同様に金敷側にも必要であるから，必要 最小限の膜厚は金敷と試験片の両表面粗さの合計值の

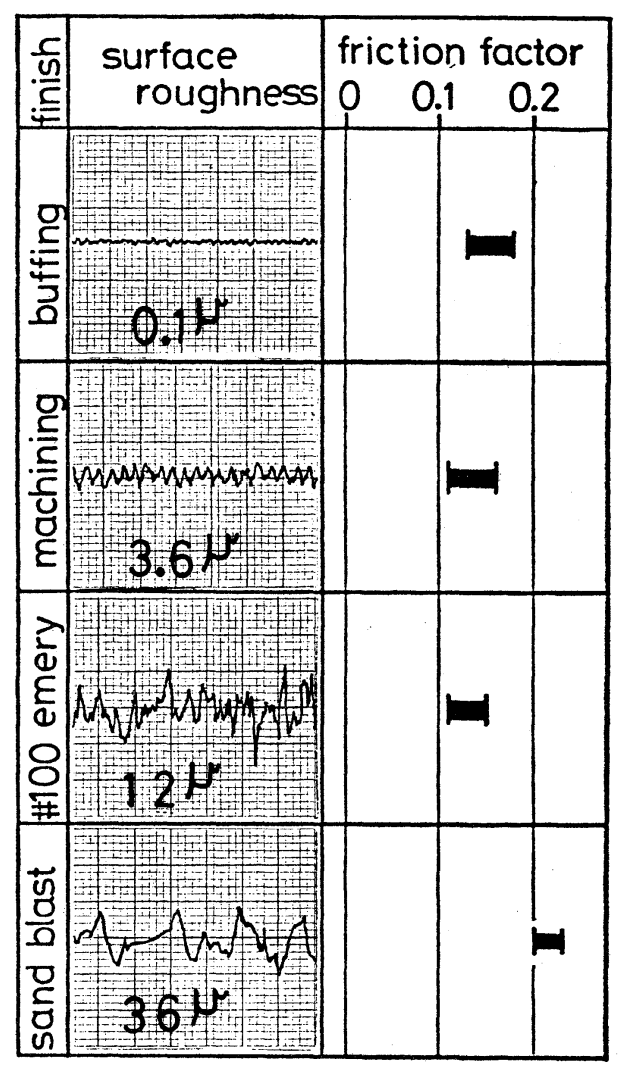

Fig. 4 Effect of specimen surface roughness on friction factor.

1/2となる。

機械加工した試験片の表面粗さは3.3 3.9 $\mu$ ，金敷の 表面粗さは2.0 2.5 $\mu$ であるから，この場合の限界潤 滑膜厚さは2.7 3.4 4 となる。この值は Fig. 3 に示し た実験值の $2.5 \mu$ とよく一致している。

鏡面仕上げなどで平滑にしすぎると $\mathrm{m}$ 值がやや増大 する。これは，潤滑剤を試験片と金敷の間にトラップし ておくためにはある程度の大きさの凹凸が必要で，それ は潤滑剂の粒度より大きな凹凸がなければならないこと を意味している。

\section{4 温度差の影響}

現場での鍛造作業では金型と素材の間に温度の差があ り，一般的に素材温度のほうが高い。したがつて，金型 と材料との界面温度は変形中に時間とともに変化する。 この温度差が潤滑性に及ぼす影響について実験した。

Fig. 5 に金敷温度を $300^{\circ} \mathrm{C}$ とし，試験片温度を 150 $450^{\circ} \mathrm{C}$ 変えて，温度差（ $\Delta \mathrm{T}$ とする）を最大 $\pm 150{ }^{\circ} \mathrm{C} に$ して測定した $\mathrm{m}$ 值を示す。金敷温度（Td とする）が試 験片温度(Ts とする)より低い場合は $\mathrm{m}$ 值がほぼ一定で あり，Td が高いとやや低くなる。しかしその変動はわ ずかである。 


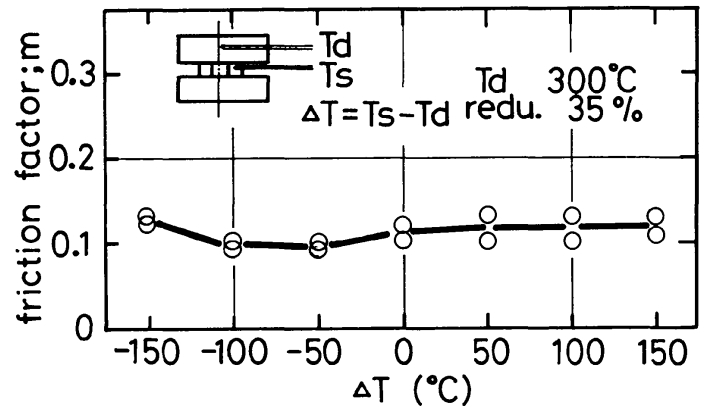

Fig. 5 Effect of temperature difference between die and specimen on friction factor. Lubricant is colloidal graphite in oil.

本実験に用いた潤滑剂の温度特性は別途に報 告する が，塗膜厚さ・表面粗さなどの諸条件を一定にした場 合, $\mathrm{m}$ 值は $250^{\circ} \mathrm{C}$ で $0.06,350^{\circ} \mathrm{C}$ で平均 $0.13,400^{\circ} \mathrm{C}$ で平 均 $0.22,450^{\circ} \mathrm{C}$ では平均 0.21 である。もし試験片の温度 によつて潤滑性が大きく影響を受けるとすれば，m 值は $\mathrm{Ts}$ が $400^{\circ} \mathrm{C}$ 以上では約 0.2 になるずなのに，実験結果

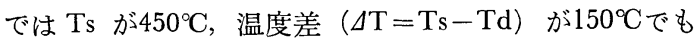
$\mathrm{m}$ 值は0.13にしかすぎない。

Fig. 6に試験片の内部と金敷・試験片界面に CA 熱電 対を挿入して, $\mathrm{Ts}$ が $400^{\circ} \mathrm{C}$ と $200^{\circ} \mathrm{C}$ とで士 $100^{\circ} \mathrm{C} の \Delta \mathrm{T}$ があ る場合について実験した温度一時間曲線を示す。この場 合試験片に約 9 ton の荷重を加えて金敷と試験片を密着 させているので，界面に挿入した熱電対先端が試験片側 に圧入され, 試験片のほうの温度を示している。試験片 内部の温度 $\mathrm{Ts}_{2}, \mathrm{Ts}_{3}$ は接触後の時間経過とともに緩や かに金型温度に近づくが，界面の $\mathrm{Ts}_{1}$ は接触後約 $5 \mathrm{sec}$ 以内で急激に金型温度 $\mathrm{Td}$ に近づく。潤滑膜の温度は $\mathrm{Td} \mathrm{d}_{1}$ との間にあると考えられるので，金敷と試験 片に与えた温度差よりも潤滑膜と試験片との温度差は少 なく，潤滑性はこれに支配されたと考えられる。

本実験は圧下速度 $2.0 \mathrm{~mm} / \mathrm{sec}$ であるから $50 \%$ 圧下す るのに約 $4 \mathrm{sec}$ 必要である。Table 2 に Fig.6 の曲 線の $0 \sim 4 \mathrm{sec}$ 間を積分して求めた $\mathrm{Ts}_{1}$ の平均温度を示す。 $\Delta \mathrm{T}$ がー $150^{\circ} \mathrm{C}$ では $240^{\circ} \mathrm{C}, \Delta \mathrm{T}$ が $+150^{\circ} \mathrm{C}$ では $375^{\circ} \mathrm{C}$ の平 均界面温度となる。使用した潤滑剤の $250 \sim 300^{\circ} \mathrm{C} て ゙ の \mathrm{~m}$ 值は0.06〜0.13の範冊であることから, Fig. 5 の結果と ほぼ一致する。

黒鉛の潤滑性は黒鉛粒子のへき開すべりと粒子間のす ベりによる11)ものであるが，潤滑膜が厚い場合はいずれ にせよ潤滑膜の内部ですべりを生ずるであろう。もし潤 滑膜の両側に温度差があり，しかもそれが潤滑性に差が 現われるほどの温度差であれば，潤滑性の良い温度側で すべりが生ずるはずである。この実験に用いた潤滑剂は 温度が高くなるほど $\mathrm{m}$ 值が高くなるので, 当然温度の

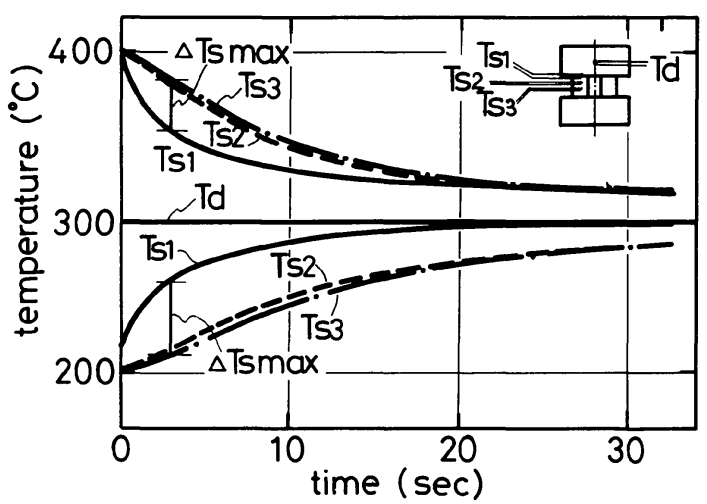

Fig. 6 Temperature-time curves when specimen temperature $(\mathrm{Ts})$ is different from die temperature $(\mathrm{Td})$.

Table 2 Mean temperature of interface in specimen and anvil durring 0 to $4 \mathrm{sec}$. from contacted.

\begin{tabular}{c|r|r|r|r|r|r|r}
\hline \hline $\begin{array}{c}\text { mean } \\
\text { tempera- } \\
\text { ture. }\end{array}$ & \multicolumn{4}{|c|}{$\Delta \mathrm{T}\left({ }^{\circ} \mathrm{C}\right)$} & temp. of anvil; $300^{\circ} \mathrm{C}$ \\
\cline { 2 - 6 } & -150 & -100 & -50 & 0 & +50 & +100 & +150 \\
\hline TS1 $\left({ }^{\circ} \mathrm{C}\right)$ & 240 & 260 & 280 & 300 & 325 & 350 & 375 \\
\hline
\end{tabular}

Table 3 Effect of compression speed on friction factor $(\mathrm{m})$. forging temperature $350^{\circ} \mathrm{C}$ Colloidal graphite in oil.

\begin{tabular}{c|c|c}
\hline $\begin{array}{c}\text { compression } \\
\text { speed } \\
(\mathrm{mm} / \mathrm{sec})\end{array}$ & $\begin{array}{c}\text { reduction in } \\
\text { height } \\
(\%)\end{array}$ & friction factor \\
\hline 0.5 & 35 & $\begin{array}{l}0.14 \\
0.13\end{array}$ \\
\hline 2.0 & 50 & 0.11 \\
7.0 & 50 & 0.10 \\
\hline \multirow{2}{*}{7.15} \\
\hline
\end{tabular}

低い側の潤滑層ですべりが生ずる。

Fig. 5 の結果では $\Delta \mathrm{T}$ が正の場合, $\Delta \mathrm{T}$ が 0 の $\mathrm{m}$ 值 と同等であり， $\Delta \mathrm{T}$ が負の場合， $\mathrm{Ts}$ が低くなるほど $\mathrm{m}$ 值がやや減少している。前者は試験片温度によらず金敷 温度で $\mathrm{m}$ 值が決まり, 後者は試験片温度によつて $\mathrm{m}$ 值 が決まるので, 試験片の温度が低いほど $\mathrm{m}$ 值は小さく なる。しかし Table2 に示したように実際の金型と試験 片の界面においては, 熱伝導のために, 与えた温度差士 $150^{\circ} \mathrm{C}$ に対して, 実測した温度差は $\pm 75^{\circ} \mathrm{C}$ 以下と大幅に 小さくなるので， $\mathrm{m}$ 值に大きな差異が現われなかつた。 一般的に熱容量は鍛造素材よりも金型のほうが大きいの で，素材の温度が高くても潤滑膜の温度は金型温度に近 ゔき，潤滑性もこの条件で作用することになる。 


\section{5 圧下速度の影響}

圧縮試験温度 $350^{\circ} \mathrm{C}$ で, 前記と同様の試験片・潤滑剂 および塗布条件にて，圧下速度を $0.5 ， 2.0 ， 7.0 \mathrm{~mm} /$ sec と変えて測定した $\mathrm{m}$ 值をTable 3 亿示す。圧下速度 が速くなるほど $\mathrm{m}$ 值が若干大きくなるが，その差は僅 少で圧下速度が大きく影響することはない。

\section{4. 結 論}

潤滑剂の比較評価にあたり,リング圧縮試験で摩擦せ し断係数の $\mathrm{m}$ 值を求めるための試験条件として $\mathrm{m}$ 值に およぼす主な因子の影響について実験し，以下の結果を 得た。

1）試験片の寸法が大きくなるほど $\mathrm{m}$ 值は大きく測 定される傾向があるが，外径 $30 \sim 75 \mathrm{~mm}$ では大きな差は なかつた。鍛造製品の肉厚を考慮すると $50 \mathrm{~mm}$ が適 当 である。

2）潤滑塗膜厚さはスプレーによつて金型表面に最初 に付着する際は, 短時間に黒鉛粒径の $1 \sim 2$ 倍の厚さに なるものの，その後はスプレー時間が長くなるほど，ま た使用する潤滑剂に適した希釈倍率の範囲でスプレーし やすい倍率にするほど厚い塗膜を作ることができる。

3）一定の圧下率まで潤滑特性を保ちながら変形する には, 金敷・試験片の表面粗さに応じた最小膜厚さ以上 の厚さが必要である。限界最小塗膜厚さは両表面粗さの
和の $1 / 2$ に相当する。

4）試験片の加熱温度を変えて, 金敷温度との間に温 度差を付けても，圧縮すると潤滑剂膜の温度は急激に両 者の中間温度に近づき，金敷温度に近い性状を示す。ま た潤滑層の厚さによつては良好な潤滑性を示す温度のほ らに従い，その温度での性状を示す。

5) 圧下速度 $0.5 \sim 7.0 \mathrm{~mm} / \mathrm{sec}$ の範囲では $\mathrm{m}$ 值の変 動は小さい。

\section{参 考 文 献}

1) J. Schey, A. Lonn: ASME 報告 No. 74-Lubs-5 (1974), 1.

2) 時沢, 山田, 松木 : 軽金属, 19 (1969), 142.

3) 河合, 中村 : 塑性と加工, 11 (1970), 798.

4) T. Altan, C. H. Lee: Trans. of ASME, Aug. (1972), 775.

5) R. A. Ketterer: $A S M E$ 報告 No. 74-Lubs-11.

6) A. Male, M. Cockeroft: Journ. of inst. of Met., 93 (1964), 39.

7) V. Nagpal, T. Altan: Battelle columbus Lab. 報告, Topical Rep. No. 11. (1976).

8) 久能木: Journ. of Sci. Inst. (Tokyo), 50 (1956), 215.

9) J. B. Haukyard: Inst. J. Mech. Sci., 9 (1967), p. 163.

10) 小坂田：塑性と加工, 12 (1971), 313.

11）土肥：固体潤滑ハンドブック，幸書房， 72 . 